\title{
Molecular epidemiology of aminoglycoside resistance in Acinetobacter spp.
}

\author{
R. J. SEWARD, T. LAMBERT* and K. J. TOWNER
}

Department of Microbiology and PHLS Laboratory, University Hospital, Queen's Medical Centre, Nottingham NG7 2 UH and *Unité des Agents Antibactériens, 28 rue du Docteur Roux, Institut Pasteur, 75724 Paris Cedex 15, France

\begin{abstract}
Most aminoglycoside resistance in Acinetobacter spp. involves production of aminoglycoside-modifying enzymes. Previous studies have shown that the genes encoding these enzymes can be present on plasmids, transposons or within integron-type structures. To determine whether particular mechanisms of aminoglycoside resistance have developed in strains from specific geographical locations (with subsequent clonal spread), or whether common mechanisms have been acquired by genotypically distinct clinical isolates of Acinetobacter spp. throughout the world, a genotypically heterogeneous collection of 24 multiresistant clinical isolates of Acinetobacter spp. from 15 hospitals in 11 countries worldwide was studied. All were resistant to two or more aminoglycoside antibiotics. The full aminoglycoside resistance profile was determined for each isolate, allowing a putative enzyme content to be inferred, with subsequent confirmation of enzyme content and genetic location by polymerase chain reaction (PCR) and hybridisation techniques. All produced at least one aminoglycoside-modifying enzyme, most commonly AAC(3)-I and ANT( $\left.3^{\prime \prime}\right)-I$ in various combinations. Other enzymes found were AAC(3)-II, AAC(6')-I, ANT( $\left(2^{\prime \prime}\right)$, APH(3')-I and APH(3')-VI. None was confined to strains from a particular geographical area. Nine isolates transferred resistance mediated by AAC(3)-I, ANT(2")-I, APH(3')-I or APH(3)'-VI by conjugation to a sensitive strain of $A$. baumannii, but most resistance was non-transferable. PCR mapping revealed an integron location in six isolates for the $\operatorname{aac}(3)-I a$ gene and in three isolates for the ant $\left(3^{\prime \prime}\right)-I a$ gene. Overall, the study demonstrated that similar aminoglycoside-modifying enzymes are found in unrelated isolates of Acinetobacter spp., and that particular genes are not restricted to specific areas of the world. The demonstration of certain genes on plasmids and integrons emphasises the probable importance of these structures in the dissemination of certain types of aminoglycoside resistance in Acinetobacter spp.
\end{abstract}

\section{Introduction}

Acinetobacter spp., particularly $A$. baumannii, cause severe nosocomial infections, especially in intensive care units [1]. Such infections have become difficult to treat as many strains are now resistant to multiple antibiotics, including the aminoglycosides, third-generation cephalosporins and fluoroquinolones [2]. Resistance rates to all the clinically useful aminoglycosides are higher in Acinetobacter spp. than any other pathogen group [3]. There are various mechanisms by which bacteria can become resistant to aminoglycosides, including alteration of the ribosomal target site and reduction of uptake $[4,5]$; however, the production of aminoglycoside-modifying enzymes is

Received 27 July 1997; accepted 18 Sept. 1997.

Corresponding author: Dr K. J. Towner. thought to account for most resistance in clinical isolates of Acinetobacter spp. [3]. Three classes of aminoglycoside-modifying enzymes exist, all of which have been found in Acinetobacter spp. [5]. These enzymes are the $O$-nucleotidyltransferases (ANT) and $O$-phosphotransferases (APH), that catalyse, respectively, the nucleotidylation (adenylation) and phosphorylation of the hydroxyl groups, and the $\mathrm{N}$-acetyltransferases (AAC), that catalyse acetylation of amino groups, so rendering the antibiotic inactive. Hybridisation data have confirmed that some strains of Acinetobacter may contain several aminoglycoside resistance genes [3].

Many factors influence the dissemination of antibiotic resistance genes. Although certain species of Acinetobacter have been shown to be intrinsically resistant to some aminoglycosides, resistance genes have also been 
found on plasmids, transposons and integrons [6-8]. The rapid emergence of resistance to aminoglycosides in clinical isolates of this genus has been attributed to their ability to acquire these resistance determinants. However, studies to date have concentrated on identifying particular enzymes and genetic determinants involved in resistance and, except on a local scale, have not investigated the epidemiological relationships of the resistant strains themselves. The purpose of the present study was to determine whether specific mechanisms of aminoglycoside resistance have developed in particular strains from defined geographical locations (with subsequent clonal spread), or whether common resistance mechanisms have been acquired by genotypically distinct clinical isolates of Acinetobacter spp. throughout the world. To address this question, the genotypic and epidemiological relationships of the isolates in this study were correlated with the aminoglycoside-modifying enzymes produced by the isolates and the genetic location of the responsible resistance determinants.

\section{Materials and methods}

\section{Bacteria}

Twenty-four Acinetobacter isolates from 15 different hospitals in 11 countries were studied (Table 1). All had been identified previously to the genomic species level by the tDNA profile method [10] and their genotypic relationships had been investigated by analysis of randomly amplified polymorphic DNA (RAPD) fingerprints obtained with M13 core region and DAF4 primers [9]. The isolates were stored at $-70^{\circ} \mathrm{C}$ in Skim Milk Powder (Oxoid) $10 \% \mathrm{w} / \mathrm{v}$ in sterile distilled water and then subcultured on to Isosensitest Agar (Oxoid), containing appropriate selective aminoglycoside antibiotics, and incubated overnight at $30^{\circ} \mathrm{C}$ before analysis. The strains used in the plasmid transfer experiments were Escherichia coli $\mathrm{K} 12$ strain $\mathrm{J} 53.2\left(\mathrm{~F}^{-}\right.$, pro, met, rif $^{\mathrm{r}}$ ) and a rifampicin-resistant mutant of $A$. baumannii type strain ATCC 19606.

\section{Aminoglycoside resistance profiles (AGRPs)}

Resistance profiles of the 24 isolates to 14 different aminoglycoside antibiotics were determined by a modified disk inhibition zone method as described previously [11]. Disks (Sanofi Diagnostics Pasteur) contained the following antibiotics ( $\mu \mathrm{g} /$ disk): kanamycin (30), neomycin (30), netilmicin (30), tobramycin (10), amikacin (30), gentamicin (10), apramycin (100), fortimicin (100), $6^{\prime}$-netilmicin (100), $2^{\prime}$-netilmicin (100), isepamicin (30), $5^{\prime}$-episisomicin (10), spectinomycin (25) and streptomycin (30). Plates were incubated for $24 \mathrm{~h}$ at $30^{\circ} \mathrm{C}$ and the diameters of the inhibition zones were measured. Similarity coefficients were then calculated and subjected to cluster analysis by the DENDRON v.2.3a program (Solltech Inc., Oakdale, IA, USA).
Table 1. Summary of the genotypic relationships of the Acinetobacter isolates included in the study

\begin{tabular}{|c|c|c|}
\hline Isolate & Identification & Source \\
\hline \multicolumn{3}{|l|}{ Group $1^{*}$} \\
\hline CW1 & A. baumannii & Nottingham, England \\
\hline CW14 & A. baumannii & Venlo, The Netherlands \\
\hline CW27 & A. baumannii & Cardiff, Wales \\
\hline CW28 & A. baumannii & East Glamorgan, Wales \\
\hline \multicolumn{3}{|l|}{ Group 2} \\
\hline CW13 & A. baumannii & Rotterdam, The Netherlands \\
\hline $\mathrm{CW} 20$ & A. baumannii & Paris, France \\
\hline $\mathrm{CW} 22$ & A. baumannii & Paris, France \\
\hline \multicolumn{3}{|l|}{ Group 3} \\
\hline CW32 & A. baumannii & Perth, Australia \\
\hline G1 & A. baumannii & Cape Town, South Africa \\
\hline G5 & A. baumannii & Cape Town, South Africa \\
\hline \multicolumn{3}{|l|}{ Group 4} \\
\hline $\mathrm{S} 4$ & A. baumannii & Singapore \\
\hline Al & A. baumannii & Buenos Aires, Argentina \\
\hline \multicolumn{3}{|l|}{ Group 5} \\
\hline $\mathrm{B} 1$ & A. baumannii & Berlin, Germany \\
\hline B5 & A. baumannii & Berlin, Germany \\
\hline \multicolumn{3}{|l|}{ Group 6} \\
\hline Di & A. baumannii & Freiburg, Germany \\
\hline D2 & A. baumannii & Freiburg, Germany \\
\hline \multicolumn{3}{|l|}{ Group 7} \\
\hline ESP41 & A. baumannii & Barcelona, Spain \\
\hline ESP77 & A. baumannii & Barcelona, Spain \\
\hline \multicolumn{3}{|c|}{ Ungrouped } \\
\hline CW5 & A. baumannii & Nottingham, England \\
\hline CW11 & Acinetobacter sp. 3 & Bristol, England \\
\hline CW31 & Acinetobacter sp. 3 & Perth, Australia \\
\hline S2 & A. baumannii & Singapore \\
\hline A16 & A. baumannii & Buenos Aires, Argentina \\
\hline I133 & A. baumannii & Trieste, Italy \\
\hline
\end{tabular}

${ }^{*}$ Isolates were included in the same genotypic group if shown previously [9] to have a similarity coefficient $\left(\mathrm{S}_{\mathrm{AB}}\right)$ value of $\geqslant 72 \%$ following analysis of RAPD fingerprints.

\section{Determination of aminoglycoside acetylating and adenylating activity}

The method of Al-Asadi et al. [12] was used in conjunction with a cellulose phosphate paper-binding system [13] to determine the presence of aminoglycoside acetylating or adenylating activity in cell extracts. Suspensions of cells grown at $30^{\circ} \mathrm{C}$ in $50 \mathrm{ml}$ of Nutrient Broth (Oxoid) were harvested by centrifugation at $4000 \mathrm{~g}$ for $15 \mathrm{~min}$ at $4^{\circ} \mathrm{C}$ and resuspended in $5 \mathrm{ml}$ of Tris- $\mathrm{HCl}$ buffer, $\mathrm{pH}$ 7.6. The cells were disrupted in an MSE ultrasonic disintegrator $(6 \times 30$-s bursts at an amplitude of $15 \mu \mathrm{m}$, with $30 \mathrm{~s}$ between bursts) on ice. The resulting preparations were tested for their ability to bind radioactivity from $1{ }^{14} \mathrm{C}$-acetyl coenzyme A (Dupont) and $8-{ }^{14} \mathrm{C}$-adenosine triphosphate (Amersham International) to gentamicin, tobramycin, amikacin and kanamycin, as described previously [12]. All tests were performed in duplicate on two occasions. Suitable facilities were not available for the determination of phosphorylating activity.

\section{Detection of aminoglycoside resistance genes}

Extraction of DNA. For extraction of whole-cell DNA, isolates were grown in nutrient broth overnight at $30^{\circ} \mathrm{C}$, the cells were harvested by centrifugation at $8000 \mathrm{~g}$ for 
$10 \mathrm{~min}$ and the DNA was extracted with DNAzol ${ }^{\mathrm{TM}}$ (GibcoBRL) reagent, used according to the manufacturer's instructions. Portions $(5 \mu 1)$ of the resulting suspensions were applied to Nylon Plus Membranes (Qiagen, Crawley, W. Sussex) and the DNA was immobilised by exposure to UV light $\left(120 \mathrm{~mJ} / \mathrm{cm}^{2}\right.$ at $254 \mathrm{~nm}$ ) in a UV Stratalinker (Stratagene) on filter paper saturated with $10 \times \mathrm{SSC}(1 \times \mathrm{SSC}$ is $150 \mathrm{mM}$ $\mathrm{NaCl}, 15 \mathrm{~mm}$ sodium citrate, $\mathrm{pH}$ 7.0). Intact chromosomal DNA and plasmid DNA were prepared in agarose plugs and separated by pulsed-field gel electrophoresis by the method of Curran et al. [14]. Following electrophoresis, discrete bands of chromosomal and plasmid (if present) DNA were transferred to Nylon Plus Membranes and cross-linked as described previously [14].

DNA hybridisation. DNA immobilised on membranes was hybridised with biotin-labelled oligonucleotide probes for seven distinct genes encoding aminoglycoside resistance: $a a c(3)-I a, a a c(3)-I I a, a a c\left(6^{\prime}\right)-I a$, $a a c\left(6^{\prime}\right)-I b$, ant $\left(2^{\prime \prime}\right)-I a$, ant $\left(3^{\prime \prime}\right)-I a$ and ant $\left(3^{\prime \prime}\right)-I b$ (Table 2) [15-22]. In addition, a probe for $a p h\left(3^{\prime}\right)-V I a$ was prepared from a 347-bp EcoRI-HindIII internal aph(3')-VIa fragment that had been cloned into plasmid pUC18 (T. Lambert, unpublished results). A suitable DNA probe was not available to detect the APH $\left(3^{\prime}\right)$-I gene. Following plasmid DNA preparation [23] from a strain of $E$. coli carrying the recombinant plasmid, the probe was isolated by EcoRI-HindIII digestion, separated by electrophoresis, extracted with a Qiaex Gel Extraction Kit (Qiagen) and biotin-labelled with a Bio-Nick Labelling System (Gibco BRL). All positive hybridisation results were detected with a BluGene Nonradioactive Nucleic Acid Detection System (Gibco BRL), with pre-hybridisation, hybridisation and detection conditions as recommended by the manufacturer.

\section{Plasmid transfer experiments}

Conjugation experiments with the rifampicin-resistant and aminoglycoside-susceptible recipient strains of $E$. coli $\mathrm{K} 12$ and the type strain of $A$. baumannii were performed with a filter-mating method [24] and overnight incubation at $30^{\circ} \mathrm{C}$. Possible transconjugants were selected on Isosensitest agar containing rifampicin $100 \mu \mathrm{g} / \mathrm{ml}$ and one of amikacin, gentamicin, kanamy- cin or tobramycin $10 \mu \mathrm{g} / \mathrm{ml}$. Transfer frequencies were expressed in terms of the number of transconjugants obtained/recipient cell.

\section{Association of aminoglycoside resistance genes with integrons}

The PCR was performed with primer sets comprising the 5'CS primer (Table 2) specific for the $5^{\prime}$ conserved sequence of Tn21-type integrons [25] and a primer for each individual aminoglycoside resistance gene (Table 2). Amplification conditions comprised 35 cycles of $1 \mathrm{~min}$ of denaturation at $94^{\circ} \mathrm{C}, 1 \mathrm{~min}$ of annealing at $55^{\circ} \mathrm{C}$ and $5 \mathrm{~min}$ of extension at $72^{\circ} \mathrm{C}$. PCR products were analysed on agarose $1.5 \% \mathrm{w} / \mathrm{v}$ gels and the sizes of any PCR products were determined by comparison with the distances migrated by pGEM DNA Markers (Promega) run on the same gel.

\section{Results \\ Comparison of aminoglycoside resistance profiles and genotypic relationships}

Table 1 shows the sources and known genotypic relationships of the isolates included in the study, based on cluster analysis of RAPD fingerprints obtained with M13 and DAF4 primers, respectively [9]. Although some isolates (those in the same group) have a close genetic relationship, the overall collection of isolates was genotypically heterogeneous. The zones of inhibition of the various aminoglycosides for the clinical isolates and the sensitive type strain of $A$. baumannii are shown in Table 3. All 24 clinical isolates were resistant to four or more aminoglycosides, with some exhibiting resistance to up to 11 of the 14 aminoglycosides tested (Table 3). Most were resistant to gentamicin, tobramycin, kanamycin, spectinomycin and streptomycin; however, all were relatively sensitive to apramycin. Fig. 1 shows the cluster analysis results obtained following analysis of the zones of inhibition. When compared with Table 1, it was apparent that some closely related isolates from the same genotypic group were unrelated in terms of their resistance to aminoglycoside antibiotics, and vice versa. Thus, for example, isolates $\mathrm{Gl}$ and G5, which are related genotypically, are unrelated according to their AGRPs, but isolates CW22 and CW32, while not related

Table 2. Oligonucleotides for hybridisation and PCR analysis

\begin{tabular}{llc}
\hline Primer or probe & Nucleotide sequence $\left(5^{\prime}\right.$ to $\left.3^{\prime}\right)$ & $\begin{array}{c}\text { Position in published } \\
\text { sequence [reference] }\end{array}$ \\
\hline $5^{\prime} \mathrm{CS}$ & GGCATCCAAGCAGCAAG & $1190-1206[15]$ \\
aac(6')-Ia & TAATTGCTGCATTCCGC & $797-781[16]$ \\
aac(6')-Ib & TGTGACGGAATCGTTGC & $432-416[17]$ \\
aac(3)-Ia & AGCCCGCATGGATTTGA & $1375-1359[18]$ \\
aac(3)-IIa & CCTCCGTTATTGCCTTC & $118-102[19]$ \\
ant(3")-Ia & TCGATGACGCCAACTAC & $464-448[20]$ \\
ant(3")-Ib & TCAATGACGCTTAGCAC & $457-441[21]$ \\
ant $\left(2^{\prime \prime}\right)-\mathrm{Ia}$ & CCGCAGCTAGAATTTTG & $1341-1325[22]$ \\
\hline
\end{tabular}




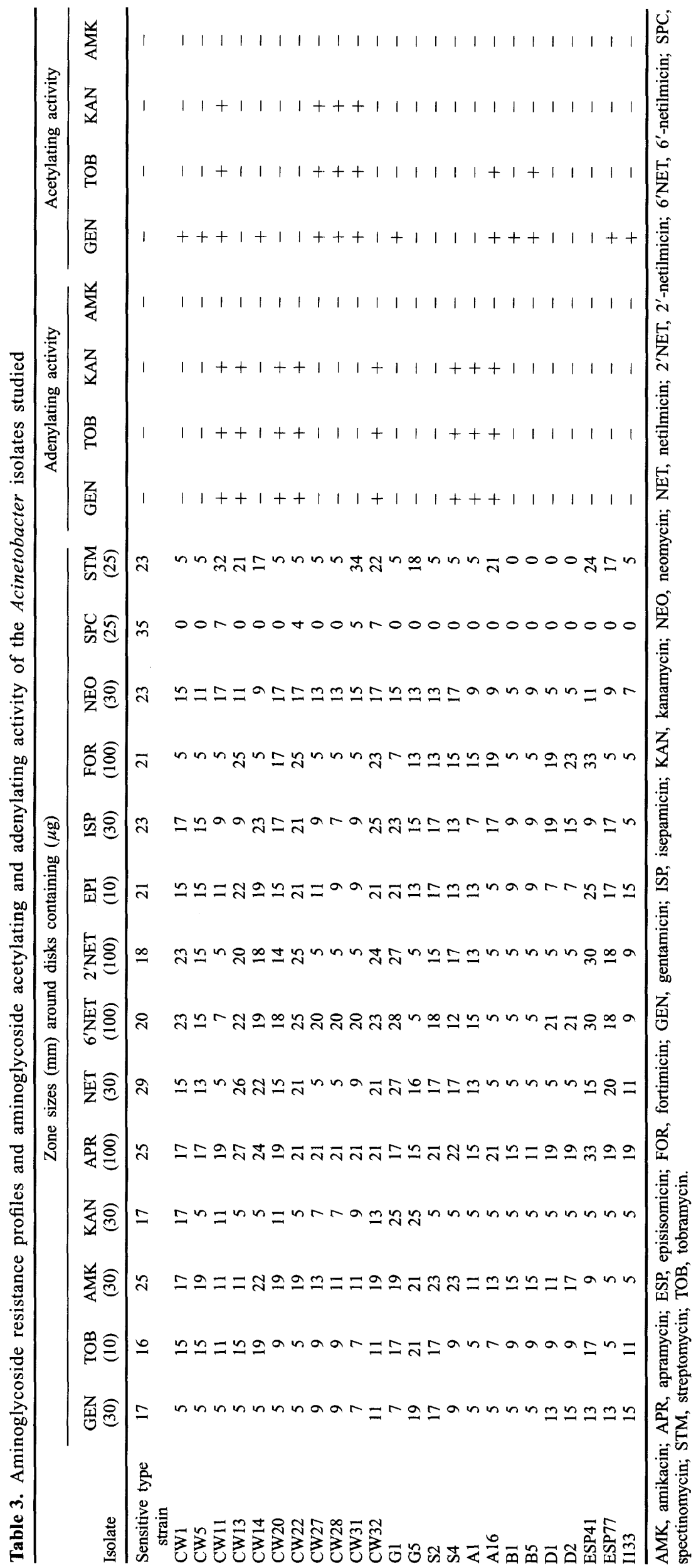




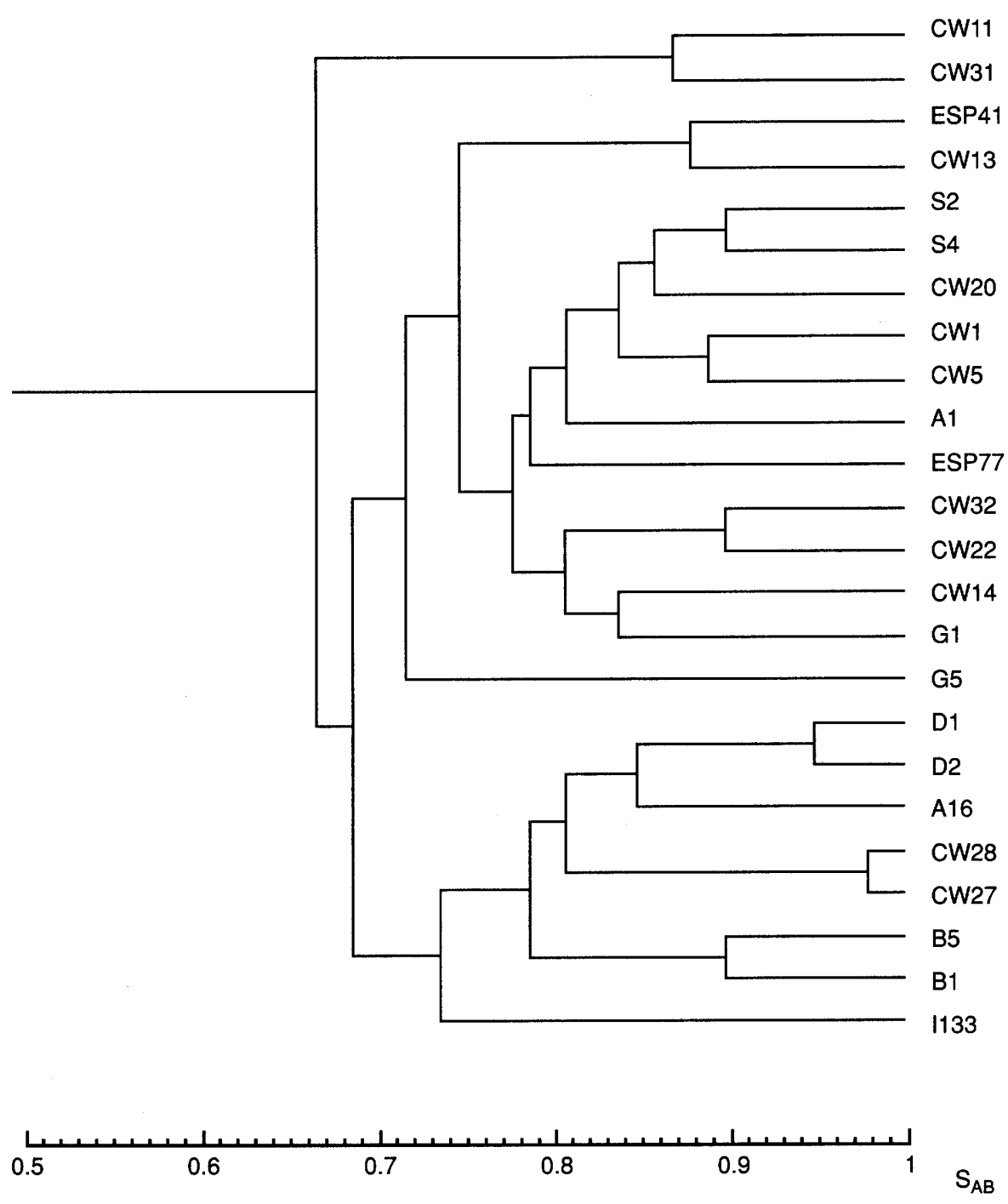

Fig. 1. Dendrogram showing the results of cluster analysis of the clinical isolates based on zones of inhibition obtained with 14 different aminoglycoside antibiotics.

genotypically, are closely related according to their AGRPs.

\section{Characterisation of aminoglycoside-modifying activity}

Also listed in Table 3 are the aminoglycoside acetylating and adenylating activities found in each individual isolate included in the study. By examining and comparing the AGRPs and the acetylating or adenylating activities of the isolates with those expected of known aminoglycoside-modifying enzymes, it was possible to deduce the probable enzyme content of the isolates [26]. On this basis, seven different enzymes were produced by the collection of isolates (Table 4). Most resistance could be attributed to the production of one or more enzymes, although one isolate had an unusual resistance pattern that was attributed, in part at least, to a change in permeability. The most common enzyme appeared to be ANT( $\left.3^{\prime \prime}\right)$-I (spectinomycin and streptomycin resistance), produced by 20 of the 24 isolates. AAC(3)-I (gentamicin and fortimicin resistance) and ANT( $\left.2^{\prime \prime}\right)$ (gentamicin, tobramycin and kanamycin resistance) also appeared to be common, being produced by 12 and eight isolates, respectively. These two enzymes were considered to be responsible for most of the gentamicin resistance within the collection of isolates. Other common enzymes were $\mathrm{APH}\left(3^{\prime}\right)-\mathrm{I}$ and $\mathrm{APH}\left(3^{\prime}\right)$-VI, produced by nine isolates each. The enzymes occurred in various combinations of between one and four enzymes in each isolate, with the combinations of $\operatorname{ANT}\left(3^{\prime \prime}\right)-\mathrm{I}$ with $\mathrm{AAC}(3)-\mathrm{I}$, and $\mathrm{ANT}\left(3^{\prime \prime}\right)$-I with $\mathrm{APH}\left(3^{\prime}\right)$-VI occuring the most frequently (in 10 and nine isolates each, respectively).

\section{Correlation of inferred aminoglycoside-modifying enzymes with hybridisation data}

Table 4 also shows the results obtained following hybridisation with the specific gene probes that were available. All the isolates failed to hybridise with the $a a c\left(6^{\prime}\right)-I a$ and ant $\left(3^{\prime \prime}\right)-I b$ probes. Those isolates that exhibited a putative ANT( $\left.3^{\prime \prime}\right)$-I profile all hybridised 
Table 4. Aminoglycoside-modifying enzymes produced by the Acinetobacter isolates included in the study

\begin{tabular}{|c|c|c|}
\hline Isolate & Enzyme content deduced from AGRPs & Genes detected by DNA-DNA hybridisation \\
\hline $\mathrm{CW} 1$ & $\mathrm{AAC}(3)-\mathrm{I}+\mathrm{ANT}\left(3^{\prime \prime}\right)-\mathrm{I}$ & $a a c(3)-I a^{*}+\operatorname{ant}\left(3^{\prime \prime}\right)-I a^{*}$ \\
\hline CW5 & $\mathrm{AAC}(3)-\mathrm{I}+\mathrm{APH}\left(3^{\prime}\right)-\mathrm{I}^{\dagger}+\mathrm{ANT}\left(3^{\prime \prime}\right)-\mathrm{I}$ & $\operatorname{aac}(3)-I a^{*}+\operatorname{ant}\left(3^{\prime \prime}\right)-I a^{*}$ \\
\hline CW11 & $\mathrm{AAC}(3)-\mathrm{I}+\mathrm{AAC}\left(6^{\prime}\right)-\mathrm{I}+\operatorname{ANT}\left(2^{\prime \prime}\right)$ & $a a c(3)-I a+a a c\left(6^{\prime}\right)-I b+a n t\left(2^{\prime \prime}\right)-I a$ \\
\hline CW13 & $\operatorname{ANT}\left(2^{\prime \prime}\right)+\operatorname{ANT}\left(3^{\prime \prime}\right)-\mathrm{I}+\mathrm{APH}\left(3^{\prime}\right)-\mathrm{VI}$ & $\operatorname{ant}\left(2^{\prime \prime}\right)-I a+\operatorname{ant}\left(3^{\prime \prime}\right)-I a+\operatorname{aph}\left(3^{\prime}\right)-V I a$ \\
\hline CW14 & $\mathrm{AAC}(3)-\mathrm{I}+\mathrm{ANT}\left(3^{\prime \prime}\right)-\mathrm{I}+\mathrm{APH}\left(3^{\prime}\right)-\mathrm{I}^{\dagger}$ & $a a c(3)-I a^{*}+\operatorname{ant}\left(3^{\prime \prime}\right)-I a^{*}$ \\
\hline CW20 & $\operatorname{ANT}\left(2^{\prime \prime}\right)+\operatorname{ANT}\left(3^{\prime \prime}\right)-\mathrm{I}$ & $\operatorname{ant}\left(2^{\prime \prime}\right)-I a+\operatorname{ant}\left(3^{\prime \prime}\right)-I a$ \\
\hline $\mathrm{CW} 22$ & $\mathrm{ANT}\left(2^{\prime \prime}\right)+\mathrm{APH}\left(3^{\prime}\right)-\mathrm{I}^{\dagger}$ & $\operatorname{ant}\left(2^{\prime \prime}\right)-I a$ \\
\hline CW27 & $\mathrm{AAC}(3)-\mathrm{I}+\mathrm{AAC}\left(6^{\prime}\right)-\mathrm{I}+\mathrm{ANT}\left(3^{\prime \prime}\right)-\mathrm{I}+\mathrm{APH}\left(3^{\prime}\right)-\mathrm{VI}$ & $a a c(3)-I a^{*}+a a c\left(6^{\prime}\right)-I b+\operatorname{ant}\left(3^{\prime \prime}\right)-I a+a p h\left(3^{\prime}\right)-V I a$ \\
\hline CW28 & $\mathrm{AAC}(3)-\mathrm{I}+\mathrm{AAC}\left(6^{\prime}\right)-\mathrm{I}+\mathrm{ANT}\left(3^{\prime \prime}\right)-\mathrm{I}+\mathrm{APH}\left(3^{\prime}\right)-\mathrm{VI}$ & $a a c(3)-I a^{*}+a a c\left(6^{\prime}\right)-I b+\operatorname{ant}\left(3^{\prime \prime}\right)-I a+a p h\left(3^{\prime}\right)-V I a$ \\
\hline CW31 & $\mathrm{AAC}(3)-\mathrm{I}+\mathrm{AAC}\left(6^{\prime}\right)-\mathrm{I}+\mathrm{APH}\left(3^{\prime}\right)-\mathrm{I}^{\dagger}$ & $a a c(3)-I a^{*}+a a c\left(6^{\prime}\right)-I b$ \\
\hline CW32 & $\operatorname{ANT}\left(2^{\prime \prime}\right)+\operatorname{APH}\left(3^{\prime}\right)-\mathrm{I}^{\dagger}$ & $\operatorname{ant}\left(2^{\prime \prime}\right)-I a$ \\
\hline G1 & $\mathrm{AAC}(3)-\mathrm{I}+\mathrm{ANT}\left(3^{\prime \prime}\right)-\mathrm{I}$ & $a a c(3)-I a+\operatorname{ant}\left(3^{\prime \prime}\right)-I a$ \\
\hline G5 & ANT $\left(3^{\prime \prime}\right)-I+$ Impermeability & $\operatorname{ant}\left(3^{\prime \prime}\right)-I a$ \\
\hline S2 & $\operatorname{ANT}\left(3^{\prime \prime}\right)-\mathrm{I}+\mathrm{APH}\left(3^{\prime}\right)-\mathrm{I}^{\dagger}$ & $\operatorname{ant}\left(3^{\prime \prime}\right)-I a$ \\
\hline S4 & $\operatorname{ANT}\left(2^{\prime \prime}\right)+\operatorname{ANT}\left(3^{\prime \prime}\right)-\mathrm{I}$ & $\operatorname{ant}\left(2^{\prime \prime}\right)-I a+\operatorname{ant}\left(3^{\prime \prime}\right)-I a$ \\
\hline A1 & $\operatorname{ANT}\left(2^{\prime \prime}\right)+\operatorname{ANT}\left(3^{\prime \prime}\right)-\mathrm{I}+\mathrm{APH}\left(3^{\prime}\right)-\mathrm{VI}$ & $\operatorname{ant}\left(2^{\prime \prime}\right)-I a+\operatorname{ant}\left(3^{\prime \prime}\right)-I a+\operatorname{aph}\left(3^{\prime}\right)-V I a$ \\
\hline A16 & $\operatorname{ANT}\left(2^{\prime \prime}\right)+\operatorname{ANT}\left(3^{\prime \prime}\right)-\mathrm{I}+\mathrm{AAC}(3)-\mathrm{II}+\mathrm{APH}\left(3^{\prime}\right)$-VI & $a a c(3)-I I a+\operatorname{ant}\left(2^{\prime \prime}\right)-I a+\operatorname{ant}\left(3^{\prime \prime}\right)-I a+\operatorname{aph}\left(3^{\prime}\right)-V I a$ \\
\hline B1 & $\mathrm{AAC}(3)-\mathrm{I}+\mathrm{ANT}\left(3^{\prime \prime}\right)-\mathrm{I}+\mathrm{APH}\left(3^{\prime}\right)-\mathrm{VI}$ & $a a c(3)-I a+a n t\left(3^{\prime \prime}\right)-I a+a p h\left(3^{\prime}\right)-V I a$ \\
\hline B5 & $\mathrm{AAC}(3)-\mathrm{I}+\mathrm{AAC}\left(6^{\prime}\right)-\mathrm{I}+\mathrm{ANT}\left(3^{\prime \prime}\right)-\mathrm{I}+\mathrm{APH}\left(3^{\prime}\right)-\mathrm{VI}$ & $a a c(3)-I a+a a c\left(6^{\prime}\right)-I b+\operatorname{ant}\left(3^{\prime \prime}\right)-I a+a p h\left(3^{\prime}\right)-V I a$ \\
\hline D1 & $\operatorname{ANT}\left(3^{\prime \prime}\right)-\mathrm{I}+\mathrm{APH}\left(3^{\prime}\right)-\mathrm{I}^{\dagger}$ & $\operatorname{ant}\left(3^{\prime \prime}\right)-I a$ \\
\hline D2 & $\operatorname{ANT}\left(3^{\prime \prime}\right)-\mathrm{I}+\operatorname{APH}\left(3^{\prime}\right)-\mathrm{I}^{\dagger}$ & $\operatorname{ant}\left(3^{\prime \prime}\right)-I a$ \\
\hline ESP41 & $\operatorname{ANT}\left(3^{\prime \prime}\right)+\operatorname{APH}\left(3^{\prime}\right)-\mathrm{VI}$ & $a n t\left(3^{\prime \prime}\right)-I a+a p h\left(3^{\prime}\right)-V I a$ \\
\hline ESP77 & $\operatorname{AAC}(3)-\mathrm{I}+\operatorname{ANT}\left(3^{\prime \prime}\right)-\mathrm{I}+\operatorname{APH}\left(3^{\prime}\right)-\mathrm{I}^{\dagger}$ & $a a c(3)-I a+\operatorname{ant}\left(3^{\prime \prime}\right)-I a$ \\
\hline I133 & $\mathrm{AAC}(3)-\mathrm{I}+\mathrm{ANT}\left(3^{\prime \prime}\right)-\mathrm{I}+\mathrm{APH}\left(3^{\prime}\right)-\mathrm{VI}$ & $a a c(3)-I a+\operatorname{ant}\left(3^{\prime \prime}\right)-I a+a p h\left(3^{\prime}\right)-V I a$ \\
\hline
\end{tabular}

*Integron-associated genes.

${ }^{\dagger}$ No DNA probe was available to detect the gene encoding $\mathrm{APH}\left(3^{\prime}\right)-\mathrm{I}$.

with the ant $\left(3^{\prime \prime}\right)-I a$ gene probe. This was also found to be the case for AAC(3)-I and $\operatorname{aac}(3)-I a, \mathrm{AAC}\left(6^{\prime}\right)-\mathrm{I}$ and $a a c\left(6^{\prime}\right)-I b$, ANT $\left(2^{\prime \prime}\right)-\mathrm{I}$ and ant $\left(2^{\prime \prime}\right)-I a$, and APH( $\left(3^{\prime}\right)$-VI and $a p h\left(3^{\prime}\right)-V I a$. Thus the hybridisation results were in complete agreement with the enzyme content inferred from the AGRPs. A DNA probe was not available to detect the APH( $\left.3^{\prime}\right)-I$ gene, but there were no positive hybridisation results that could not be accounted for by reference to the enzyme profiles.

\section{Location of aminoglycoside resistance genes}

Transfer of aminoglycoside resistance from the clinical isolates to $E$. coli $\mathrm{K} 12$ was not detected (transfer frequency of $<2 \times 10^{-10}$ ). However, of the 24 strains, nine transferred one or more resistances to a sensitive strain of $A$. baumannii at frequencies of between $5 \times 10^{-6}$ and $1.6 \times 10^{-4}$ (Table 5). Hybridisation of DNA separated on pulsed-field gels with the available probes revealed that two ant $\left(2^{\prime \prime}\right)-I a$ genes were present on plasmids detected in two of the 24 isolates (isolates CW32 and A16), but DNA probes for 41 of the total of 55 genes detected were found to hybridise to the intact chromosome. The remaining 12 genes may have been located on plasmids that were not separated by pulsedfield gel electrophoresis; indeed, nine were shown to be transferable in conjugation experiments (Table 5). In addition, the location of the genes encoding resistance mediated by the APH( $\left.3^{\prime}\right)$-I enzyme could not be deduced because of the lack of an available probe. PCR analysis with the $5^{\prime} \mathrm{CS}$ primer and the primer for the $a a c(3)-I a$ gene yielded a product of $200 \mathrm{bp}$ from six isolates (Table 4). Three of these isolates also yielded a product of $2.7 \mathrm{~kb}$ with the $5^{\prime} \mathrm{CS}$ primer and that specific for the ant( $\left.3^{\prime \prime}\right)$-Ia gene (Table 4). However,
Table 5. Aminoglycoside resistance genes transferred from clinical isolates to the sensitive type strain of $A$. baumannii

\begin{tabular}{|c|c|c|}
\hline Isolate & $\begin{array}{l}\text { Gene or enzyme } \\
\text { activity transferred }\end{array}$ & Transfer frequency* \\
\hline CW1 & $a a c(3)-I a$ & $2 \times 10^{-5}$ \\
\hline CW5 & $a a c(3)-I a$ & $5 \times 10^{-6}$ \\
\hline CW13 & $\operatorname{ant}\left(2^{\prime \prime}\right)-I a+\operatorname{aph}\left(3^{\prime}\right)-V I a$ & $6.4 \times 10^{-5}+9.6 \times 10^{-5}$ \\
\hline S2 & $\mathrm{APH}\left(3^{\prime}\right)-\mathrm{I}$ & $5.4 \times 10^{-5}$ \\
\hline $\mathrm{Al}$ & $\operatorname{ant}\left(2^{\prime \prime}\right)-I a+a p h\left(3^{\prime}\right)-V I a$ & $5.6 \times 10^{-5}+1.6 \times 10^{-4}$ \\
\hline A16 & ant $\left(2^{\prime \prime}\right)-I a$ & $1.3 \times 10^{-4}$ \\
\hline ESP41 & $a p h\left(3^{\prime}\right)-V I a$ & $3.9 \times 10^{-5}$ \\
\hline ESP77 & $\mathrm{APH}\left(3^{\prime}\right)-\mathrm{I}+a a c(3)-I a$ & $1.6 \times 10^{-5}$ \\
\hline $\mathrm{I} 133$ & $a a c(3)-I a+a p h\left(3^{\prime}\right)-V I a$ & $4.7 \times 10^{-5}+4.9 \times 10^{-5}$ \\
\hline
\end{tabular}

${ }^{*}$ Number of transconjugants/recipient cell.

the other isolates carrying the aac(3)-Ia or ant( $\left.3^{\prime \prime}\right)-I a$ genes (six and 14 isolates respectively), did not yield integron-associated products. No other integron-associated products were detected with any of the other primer combinations investigated.

\section{Discussion}

The primary aim of this study was to investigate whether particular aminoglycoside-modifying enzymes produced by clinical isolates of Acinetobacter spp. had evolved in and were confined to specific genotypes of this genus (with subsequent clonal spread), or whether the same resistance mechanisms were being acquired independently by unrelated genotypes, and if so, the nature of the genetic processes involved. The isolates included in the study were obtained from worldwide locations and were known from a previous study [9] to be genotypically heterogeneous. However, based on the 
current consensus similarity value of $72 \%$ used to group genotypically related isolates of Acinetobacter $[11,27]$, seven related groups of isolates could be distinguished (Table 1). When the cluster analysis results based on aminoglycoside inhibition zones (Fig. 1) were compared with the genotypic groupings, it was apparent that isolates sharing the same AGRPs were found in different genotypic groups, indicating that the same resistance mechanisms may be shared by diverse groups of isolates.

To examine this point further, the aminoglycosidemodifying enzyme content of the various isolates was first deduced by analysis of the AGRPS and aminoglycoside-modifying activity found in cell extracts, and was then confirmed by the use of specific aminoglycoside gene probes. The hybridisation results were in complete agreement with the enzyme content inferred for each isolate from its AGRP. Seven different enzymes were produced by the collection of isolates (Table 4), often in combination. AAC(3)-I and $\operatorname{ANT}\left(2^{\prime \prime}\right)$, found in several genotypic groups, were responsible for most of the gentamicin resistance observed. Similarly, the other five enzymes were also found in genotypically unrelated isolates. Thus, based on the limited number of isolates examined, it appeared from these results that the same aminoglycoside resistance genes were distributed amongst several genotypically distinct groups of isolates. Attempts to transfer resistance from the clinical isolates to $E$. coli were unsuccessful, but transfer of certain resistance genes was detected from nine isolates to a sensitive type strain of $A$. baumannii (Table 5). Potential mobilisation of transposons from the chromosome of the resistant clinical isolates to other bacteria remains to be investigated, but the $a a c(3)-I a$ and ant (3")-Ia genes were shown by PCR analysis to be associated with Tn2I-type integron structures in six isolates. Integrons are novel genetic elements that include the determinants of a site-specific recombination system capable of capturing and mobilising genes that are contained in discrete mobile gene cassettes [28]. They are thought to be involved in the spread and formation of new combinations of antibiotic resistance determinants in a wide range of gram-negative bacteria [29] and can be located either on plasmids or can become stably inserted into the chromosome as part of transposition-type processes $[30,31]$.

In conclusion, this study demonstrated that similar aminoglycoside-modifying enzymes are found in unrelated isolates of Acinetobacter spp. and that particular genes are not restricted to specific areas of the world. It seems that certain aminoglycoside resistance genes have become disseminated in Acinetobacter spp. by a range of genetic mechanisms, including transfer on plasmids and integron-type structures. Such genetic mechanisms have already been shown to be involved in the global dissemination of mercury-resistance amongst environmental isolates of Acinetobacter spp. [32]. The association of these various genetic structures with resistance to antibiotics other than aminoglycosides, and their importance in the dissemination of such resistance, remains to be determined.

\section{References}

1. Bergogne-Bérézin E, Towner KJ. Acinetobacter spp. as nosocomial pathogens: microbiological, clinical, and epidemiological features. Clin Microbiol Rev 1996; 9: 148-165.

2. Vila J, Marcos A, Marco F et al. In vitro antimicrobial production of $\beta$-lactamases, aminoglycoside-modifying enzymes and chloramphenicol acetyltransferase by and susceptibility of clinical isolates of Acinetobacter baumannii. Antimicrob Agents Chemother 1993; 37: 138-141.

3. Miller GH, Sabatelli FJ, Naples L, Hare RS, Shaw KJ. The most frequently occurring aminoglycoside resistance mechanisms - combined results of surveys in eight regions of the world. $J$ Chemother 1995; 7 Suppl 2: 17-30.

4. Ahmad $\mathrm{MH}$, Rechenmacher A, Böck A. Interaction between aminoglycoside uptake and ribosomal resistance mutations. Antimicrob Agents Chemother 1980; 18: 798-806.

5. Shannon K, Phillips I. Mechanisms of resistance to aminoglycosides in clinical isolates. J Antimicrob Chemother 1982; 9: 91-102.

6. Devaud M, Kayser FH, Bächi B. Transposon-mediated multiple antibiotic resistance in Acinetobacter strains. Antimicrob Agents Chemother 1982; 22: 323-329.

7. Amyes SGB, Young H-K. Mechanisms of antibiotic resistance in Acinetobacter spp. - genetics of resistance. In: BergogneBérézin E, Joly-Guillou ML, Towner KJ (eds) Acinetobacter: microbiology, epidemiology, infections, management. Boca Raton, CRC Press. 1996: 185-223.

8. Murray BE, Moellering RC. Evidence of plasmid-mediated production of aminoglycoside-modifying enzymes not previously described in Acinetobacter. Antimicrob Agents Chemother 1980; 17: 30-36.

9. Ehrenstein B, Bernards AT, Dijkshoorn L et al. Acinetobacter species identification by using tRNA spacer fingerprinting. $J$ Clin Microbiol 1996; 34: 2414-2420.

10. Seward RJ, Ehrenstein B, Grundmann HJ, Towner KJ. Direct comparison of two commercially available computer programs for analysing DNA fingerprinting gels. J Med Microbiol 1997; 46: $314-320$.

11. Webster CA, Towner KJ, Humphreys H, Ehrenstein B, Hartung D, Grundmann H. Comparison of rapid automated laser fluorescence analysis of tDNA fingerprints with four other computer-assisted approaches for studying relationships between Acinetobacter baumannii isolates. $J$ Med Microbiol 1996; 44: 185-194.

12. Al-Asadi MJS, Towner K, Greenwood D. Acquired cross resistance to aminoglycosides in gentamicin-sensitive and gentamicin-resistant strains of enterobacteria. $J$ Med Microbiol 1981; 14: 171-183.

13. Benveniste R, Davies J. Mechanisms of antibiotic resistance in bacteria. Annu Rev Biochem 1973; 42: 471-506.

14. Curran R, Hardie KR, Towner KJ. Analysis by pulsed-field gel electrophoresis of insertion mutations in the transferrin-binding system of Haemophilus influenzae type b. J Med Microbiol 1994; 41: 120-126.

15. Bissonnette L, Roy PH. Characterization of In0 of Pseudomonas aeruginosa plasmid pVS1, an ancestor of integrons of multiresistance plasmids and transposons of gram-negative bacteria. J Bacteriol 1992; 174: 1248-1257.

16. Tenover FC, Filpula D, Philips KL, Plorde JJ. Cloning and sequencing of a gene encoding an aminoglycoside $6^{\prime}-N$ acetyltransferase from an $\mathrm{R}$ factor of Citrobacter diversus. $J$ Bacteriol 1988; 170: 471-473.

17. Tran Van Nhieu G, Collatz E. Primary structure of an aminoglycoside $6^{\prime}-N$-acetyltransferase, $\mathrm{AAC}\left(6^{\prime}\right)-4$, fused in vivo with the signal peptide of the $\operatorname{Tn} 3$-encoded- $\beta$-lactamase. $J$ Bacteriol 1987; 169: 5708-5714.

18. Wohlleben W, Arnold W, Bissonnette L et al. On the evolution of Tn2I-like multiresistance transposons: sequence analysis of the gene $(a a c C l)$ for gentamicin acetyltransferase-3-1 (AAC(3)-I), another member of the $\operatorname{Tn} 21$-based expression 
cassette. Mol Gen Genet 1989; 217: 202-208.

19. Vliegenthardt JS, Ketelaar-van Gaalen PAG, van der Klundert JAM. Nucleotide sequence of the aacC2 gene, a gentamicin resistance determinant involved in a hospital epidemic of multiply resistant members of the family Enterobacteriaceae. Antimicrob Agents Chemother 1989; 33: 1153-1159.

20. Hollingshead S, Vapnek D. Nucleotide sequence analysis of a gene encoding a streptomycin/spectinomycin adenyltransferase. Plasmid 1985; 13: 17-30.

21. Tait RC, Rempel H, Rodriguez RL, Kado CI. The aminoglycoside-resistance operon of the plasmid $\mathrm{pSa}$ : nucleotide sequence of the streptomycin-spectinomycin resistance gene. Gene 1985; 36: $97-104$.

22. Cameron FH, Groot Obbink DJ, Ackerman VP, Hall RM. Nucleotide sequence of the $\operatorname{AAD}\left(2^{\prime}\right)$ aminoglycoside adenylyltransferase determinant $a a d B$. Evolutionary relationship of this region with those surrounding aadA in R538-1 and $d h f r I I$ in R388. Nucleic Acids Res 1986; 14: 8625-8635.

23. Silhavy TJ, Berman ML, Enquist LW. Methods for rapid plasmid DNA isolation. In: Experiments with gene fusions. Cold Spring Harbor, NY, Cold Spring Harbor Laboratory. 1984: 147-151.

24. Towner KJ, Vivian A. RP4-mediated conjugation in Acinetobacter calcoaceticus. $J$ Gen Microbiol 1976; 93: 355-360.

25. Lévesque C, Piché L, Larose C, Roy PH. PCR mapping of integrons reveals several novel combinations of resistance genes. Antimicrob Agents Chemother 1995; 39: 185-191.

26. Lambert T, Rudant E, Bouvet P, Courvalin P. Molecular basis of aminoglycoside resistance in Acinetobacter spp. In: Towner $\mathrm{KJ}$ (ed) Clinical importance and antibiotic resistance of Acinetobacter spp. J Med Microbiol 1997: 46: 731-735.

27. Grundmann H, Schneider Ch, Tichy HV et al. Automated lase fluorescence analysis of randomly amplified polymorphic DNA a rapid method for investigating nosocomial transmission of Acinetobacter baumannii. J Med Microbiol 1995; 43: 446-451.

28. Stokes HW, Hall RW. A novel family of potentially mobile DNA elements encoding site-specific gene-integration functions: integrons. Mol Microbiol 1989; 3: 1669-1683.

29. Sallen B, Rajoharison A, Desvarenne S, Mabilat C. Molecular epidemiology of integron-associated antibiotic resistance genes in clinical isolates of Enterobacteriaceae. Microb Drug Resis 1995; 1: 195-202.

30. Francia MV, de la Cruz F, García Lobo JM. Secondary sites for integration mediated by the Tn21 integrase. Mol Microbiol 1993; 10: 823-828.

31. Recchia GD, Hall RM. Plasmid evolution by acquisition of mobile gene cassettes: plasmid pIE723 contains the aadB gene cassette precisely inserted at a secondary site in the IncQ plasmid RSF1010. Mol Microbiol 1995; 15: 179-187.

32. Yurieva $\mathrm{O}$, Kholodii $\mathrm{G}$, Minakhin $\mathrm{L}$ et al. Intercontinental spread of promiscuous mercury-resistance transposons in environmental bacteria. Mol Microbiol 1997; 24: 321-329. 